\title{
Fallopian Tube Cancer Pathologic Regional Lymph Nodes TNM Finding v7
}

National Cancer Institute

\section{Source}

National Cancer Institute. Fallopian Tube Cancer Pathologic Regional Lymph Nodes TNM Finding V7. NCI Thesaurus. Code C89682.

A pathologic finding about one or more characteristics of fallopian tube cancer, following the rules of the TNM AJCC V7 classification system as they pertain to staging of regional lymph nodes. 